Available online at GSC Online Press Directory

GSC Biological and Pharmaceutical Sciences

e-ISSN: 2581-3250, CODEN (USA): GBPSC2

Journal homepage: https://www.gsconlinepress.com/journals/gscbps

(RESEARCH ARTICLE)

\title{
Prevalence of rotavirus infection in diarrheic newborn calves in Abidjan region, Ivory Coast
}

\author{
Monney Jacques D. ${ }^{1}$, Adjogoua Valery E. ${ }^{2}$, Karamoko Yahaya ${ }^{1,{ }^{*}}$ and Akran Veronique ${ }^{2}$ \\ ${ }^{1}$ Nature Sciences Training and Research Unit, Animal Biology and Cytology Laboratory, Nangui Abrogoua University. 02 \\ BP 801 Abidjan 02, Ivory Coast. \\ 2 Virology departement of Institut Pasteur, 01 BP490 Abidjan 01, Ivory Coast.
}

Publication history: Received on 15 October 2018; revised on 01 November 2018; accepted on 05 November 2018

Article DOI: https://doi.org/10.30574/gscbps.2018.5.2.0116

\begin{abstract}
The aim of the current study was to identify the prevalence of rotavirus infection in newborn calves aged from 1 day to 3 months old in Abidjan region. A total of 145 fecal samples were collected from both diarrheic ( $\mathrm{n}=135)$ and nondiarrheic $(n=10)$ neonatal calves. Neonatal calves' fecal samples were collected in dry seasons and in rainy seasons in Abidjan and suburbs from 2015 to 2017. Investigated calves were divided into 4 age groups (1-10 days old, 10-25 days old, 25-60 days old and $\leq 90$ days old). All samples were screened for the presence of rotavirus antigen by ELISA kit. Among the 145 feces samples examined by ELISA, 19 were identified positive (13.10\%). Infection prevalence peaked have been obtained at $10-25$ days of age and in the rainy season. The prevalence was higher in suburbs and during the rainy season. The present study showed that rotaviruses are involved in the neonatal calves' diarrhea in Abidjan area.
\end{abstract}

Keywords: Calf; Diarrhea; Rotavirus; Prevalence; ELISA

\section{Introduction}

Rotaviruses are the important etiological agents of acute viral gastroenteritis in young one of many animals' species and human $[1,2]$. Rotavirus infections cause significant economic losses in neonates of many domestic animals. Neonatal calf mortality in the first month of age is accounted to be 80 to $85 \%$ of the total mortality and is particularly high in the third week of life [3, 4]. Rotaviruses are classified in the genus Rotavirus in the family Reoviridaea. They are characterized by segmented genome including 11 segments of double stranded RNA contained within a triple layered protein shell composed of a core, inner capsid and outer capsid. Three structural proteins, VP1, VP2 and VP3, form the core of the rotavirus particle $[5,6]$. The high frequency and persistence of calves' neonatal diarrhea in farming has gained the interest of many researchers. The purpose of the present study is to estimate the prevalence of rotavirus using ELISA assay in diarrheic feces from calves and it's interaction with parameters such us age-group, sex, localities and seasons.

\section{Material and methods}

\subsection{Study area}

The study area is located in Abidjan (south of Ivory Coast).The breeding system encountered in Ivory Coast is the extensive system. Some samples are from Yopougon and Port- Bouet of Abidjan city; and others from Bingerville (about $10 \mathrm{~km}$ from Abidjan) and Anyama (about $20 \mathrm{~km}$ from Abidjan), which are Abidjan suburbs (Figure 1). Four seasons are observed in south of Ivory Coast: two rainy seasons and two dry seasons.

\footnotetext{
${ }^{*}$ Corresponding author

E-mail address: y.karamoko@gmail.com
} 


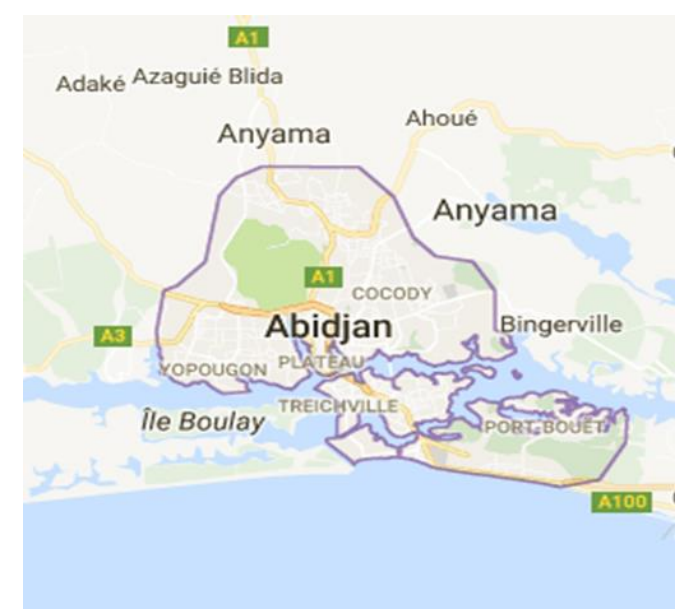

Figure 1 Map of Abidjan indicates sampling sites

\subsection{Samples collection}

145 fecal samples (135 diarrheic and 10 non-diarrheic) were collected in dry and rainy season during study period 2015-2017. The population was stratified into four age groups: 14 calves were 1 to 10 days old, 69 were 10 to 25 days old, 40 were 25 to 60 days old, and 22 were 60 to 90 days old. Samples were from both sexes of calves. The sample sizes for the sites and seasons are shown in Table 1.Stools were collected directly into the rectum using gloves in sterile flasks. The samples were transported in a frost containing cold accumulators and stored at $-20^{\circ} \mathrm{C}$ until further processing.

Table 1 Sample sizes and provenance

\begin{tabular}{lllll}
\hline Sampling sites & \multicolumn{2}{c}{ Dry season } & \multicolumn{2}{c}{ Rainy season } \\
\cline { 2 - 5 } & D calves & N D calves & D calves & N D calves \\
\hline Yopougon & 5 & 1 & 16 & 2 \\
Port-Bouet & 3 & 1 & 15 & 1 \\
Bingerville & 15 & 1 & 33 & 1 \\
Anyama & 21 & 1 & 27 & 2 \\
\hline \multicolumn{3}{c}{ D= diarrheic and N D= non-diarrheic }
\end{tabular}

\subsection{Rotavirus detection}

\subsubsection{Screening by ELISA}

ELISA was performed to detect group A rotavirus antigen in the fecal samples as described by the kit manufacturer (ProSpecTTM Rotavirus, reference R240396). After adding stop solution ( $0.46 \mathrm{~mol} / \mathrm{L} \mathrm{of} \mathrm{H2SO4),} \mathrm{the} \mathrm{optical} \mathrm{density} \mathrm{(OD)}$ of each well was measured at $450 \mathrm{~nm}$. Calculating the net OD of each sample and interpreting the results were performed as described by manufacturer instruction. Briefly, all samples were considered positive if the value of sample is upper or equal to the threshold value. The threshold value is obtained by adding 0.1 absorbance unit to the negative control value.

\subsection{Statistical analysis}

$$
\text { The prevalence }(\%)=\frac{\text { Number of samples positive for bovine rotavirus }}{\text { Total number of diarrhoea samples screened }} \times 100
$$

The proportions of the various studied parameters were subjected to a chi-squared test to evaluate their significant level. The statistical tests were carried out with the R version 2.12.1 software. The prevalences were significant at $5 \%$. 


\section{Results}

Results have shown a rotavirus prevalence of $13.10 \%$ of calves 'diarrheic fecal in group A. Non diarrheic samples were negative (Table 2).

Table 2 Distribution of bovine rotavirus in screened diarrhoeic samples

\begin{tabular}{|c|c|c|c|c|c|}
\hline \multicolumn{2}{|c|}{ Type of distributions } & $\begin{array}{c}\text { Number of } \\
\text { diarrhoea samples } \\
\text { screened }\end{array}$ & $\begin{array}{c}\text { Number of samples } \\
\text { positive for bovine } \\
\text { rotavirus }\end{array}$ & $\begin{array}{c}\text { Prevalence } \\
(\%)\end{array}$ & $\chi^{2}$ \\
\hline \multicolumn{2}{|l|}{ Diarrheic } & 135 & 19 & 13.10 & \\
\hline \multicolumn{2}{|c|}{ Non-diarrheic } & 10 & 0 & 0 & \\
\hline \multirow[t]{2}{*}{ Sex } & Males & 80 & 11 & $13.75^{\mathrm{a}}$ & \\
\hline & Females & 65 & 8 & $12.30^{a}$ & 0.081 \\
\hline \multirow[t]{4}{*}{ Age } & Group I (1-10days) & 14 & 1 & $7.14^{\mathrm{b}}$ & 4.07 \\
\hline & Group II (10-25days) & 69 & 11 & $15.94^{b}$ & \\
\hline & Group III (25-60 days) & 40 & 5 & $12.5^{\mathrm{b}}$ & \\
\hline & Group VI (60-90 days) & 22 & 2 & $9 b$ & \\
\hline \multirow[t]{3}{*}{ Seasons } & Dry season & 48 & 4 & $8.33^{c}$ & \\
\hline & Rainy season & 97 & 15 & $15.46^{c}$ & 2.170 \\
\hline & Yopougon & 29 & 3 & $10.34^{\mathrm{d}}$ & \\
\hline \multirow{3}{*}{$\begin{array}{l}\text { Localities } \\
\text { distribution }\end{array}$} & Port-Bouet & 15 & 1 & $6.66^{d}$ & \\
\hline & Bingerville & 58 & 9 & $15.5^{\mathrm{d}}$ & 4.263 \\
\hline & Anyama & 43 & 6 & $13.95^{\mathrm{d}}$ & \\
\hline
\end{tabular}

In the same column, the values followed by the same letter are not statistically different $(\mathrm{P}>0.05)$.

\subsection{Age distribution of bovine rotavirus in neonatal calves}

Distribution of antigen positive samples corresponding to ages was shown in table 2 . The results indicate a prevalence of $15 \%$ for calves aged 10 to 20 days of age. This shows that new born calves of 10 to 25 days age group were more susceptible to rotavirus infection. The rotavirus prevalence's was not significant $(\mathrm{P}>0.05)$ between age classes.

\subsection{Prevalence of rotavirus according localities}

The prevalence was higher in the suburbs than communes of Abidjan city, with a prevalence of 29\% (Table 2).The rotavirus prevalence was not significant $(\mathrm{P}>0.05)$ between localities.

\subsection{Prevalence of rotavirus according seasons}

New born calves were more susceptible to rotavirus infection in rainy seasons (Table 2). The result showed a prevalence of $15.46 \%$. The rotavirus prevalence was not significant $(\mathrm{P}>0.05)$ for seasons.

\subsection{Sex distribution of bovine rotavirus in neonatal calves}

The result indicated that $13,75 \%$ male calves were found positive, whereas rotavirus was detected in 8 of 65 (12.30\%) samples of female calves (Table 2). The prevalences were not significant $(\mathrm{P}>0.05)$ for rotavirus between male and female.

\section{Discussion}

Rotavirus infection is considered as the basic cause of diarrhea and enteritis in calves [7- 9]. In this study, 145 fecal samples screened using ELISA, rotaviral infection of group A was found in $n=19$ of diarrheic calves when all nondiarrheic calves were negative. The overall prevalence was found to be $13.10 \%$ in diarrheic calves with a higher rate in suburbs of Abidjan. A study conducted by Akran et al. [10] in 2004, the prevalence of 2.94\% from 68 samples has been reported from different parts of Ivory Coast (Toumodi and Abidjan region).The discrepancy of results could be 
attributed to the time elapsed since 2004 and the sample size. Prevalence rate of rotavirus have been reported from many countries including 8.92\% in Turkey [11], 14.63\% in Algeria [12], 15\% in Vietnam [13], 16.8\% in Southern Italy [14], 27.02\% in India [15] and 58.7\% in Switzerland [16]. Prevalence of rotaviral infection varies depending on the country and region under study [17-18].

The result showed that 11 of $80(13.75 \%)$ male calves were found positive whereas rotavirus was detected in 8 of 65 $(12.30 \%)$ samples of female calves. The possible reason for this might be that more number of samples were collected from male calves. Another possible justification for this could be due to immune system. Odde [19] reported higher IgG concentrations for heifers compared to male calves. Observations reported by Ammar [20] and Dash et al. [21] showed higher susceptibility of male bovine calves were found in comparison to female calves.

Age wise susceptibility was also evaluated. The result indicated that newborn calves of 10 to 60 days of age were more susceptible to rotavirus infection. The most exposed were calves from 10 to 25 days of age and the occurrence of rotavirus infection declined with advancing age. Similarly, the earlier workers also reported higher occurrence of rotavirus diarrhea in neonatal calves from $1^{\text {st }}$ week to $8^{\text {th }}$ week of age [22-24].

The results show that the prevalence is higher in the suburbs (Anyam and Bingerville) than in the city of Abidjan. The possible justification could be attribute to population behaviour in these areas. Children defecate in the scrub and near farms; this can be a source of contamination for animals.

Fecal samples collected during the rainy season showed higher rotavirus positivity than in dry season. This corroborate with Nourmohammadzadeh et al. [25]and Fields et al. [26] who reported low temperature and relative humidity increase the survival of rotavirus.

\section{Conclusion}

This study indicates the presence of rotavirus infection in calves' diarrhea fecal in Abidjan. It would be important to understand the dynamics of rotavirus transmission, cycle and to identify alternative management practices to minimize the risk factors.

\section{Compliance with ethical standards}

\section{Acknowledgments}

The authors gratefully acknowledge the technical staff of Virology departement of Institut Pasteur, Ivory Coast.

\section{Disclosure of conflict of interest}

The authors have no conflict of interest to declare.

\section{References}

[1] Kapikian AZ and Chanock RM. (1996). Rotaviruses. Fields Virology, 4th ed. Lippincott Williams and Wilkins, Philadelphia, 1657-1708.

[2] Bendali F, Bichet H, Schelcher F and Sana M. (1999). Pattern of diarrhoea in newborn beef calves in South-West. Veterinary research, 30(1), 61-74.

[3] Snodgrass DR, Terzolo HR, Campbell D, Sherwood I, Menzies JD and Synge BA. (1986). Etiology of diarrhea in young calves. Veterinay Record Journal. 119(4), 31-34.

[4] Singh DD, Kumar M, Choudhary PK. and Singh HN. (2009). Néonatal calf mortality. IntasPolivet, 10(4), 165-169.

[5] Gazal S, Taku AK and Kumar B. (2011). Predominance of rotavirus genotype G6P in diarrhoeic lambs. Vetenary Journal., 193(2), 299-300.

[6] Matthijnssens], Ciarlet M, Mcdonald SM, Attouih H and Banyai K.(2011).Uniformity of rotavirus strain nomenclature proposed by the Rotavirus Classification Working Group (RCWG). Arch. Virol, 156(4), 1397-1413. 
[7] L'haridon R and Scherrer R. (1976). In vitro culture of rotavirus associated with neonatal diarrhea in the calf. Annals of Veterinary Research, 7(4), 373-381.

[8] Rathi R, Kadian SK, Khurana B, Grover YP and Gulati BR. (2007).Evaluation of immune response to bovine rotavirus following oral and intraperitonial inoculation in mice. Indian Journal of Experimental Biology, 45(2), 212-216.

[9] Trojnar E, Sachsenroder J, Twardziok S, Reetz J, Otto PH and Johne R. (2013). Identification of an avian group A rotavirus containing a novel VP4 gene of close relationship to those of mammalian rotaviruses. Journal of General Virology, 94(6), 136-142.

[10] AkranV, Akou-Koffi C, Geyer A, Ekaza, Peenze I and Dosso M. (2009). Rotavirus infection of calves and pigs in Ivory Coast during the period 2003-2004. Bio-Africa review, 2009(7), 18-27.

[11] Volkan Y. (2016). Investigation of Rotavirus Infection in Calves with Diarrhea in Northeast Turkey. Animal and Veterinary Sciences, 4(1), 1-4.

[12] Selles S, Belhamiti B, Ait, Benia A, Bellik Yuva1, Hammoudi S and Niar A.(2014). Prevalence of rotavirus (GARV) and coronavirus $(\mathrm{BCoV})$ associated with neonatal diarrhea in calves in western Algeria. Asian Pacific Journal Tropical Biomedicine, 4(1), S318-S322.

[13] Helena Kyle. (2007). Rotavirus infection in dairy calves in Southern Vietnam Faculty of Veterinary Medicine Animal Sciences. Degree project 2007:60 and ISSN 1652-697.

[14] Pisanelli G, Martella V, Pagnini U, Demartino L, Lorusso E, Iovane G and Buonavogalia C. (2005). Distribution of G (VP7) and (VP4) genotypes in buffalo group A rotaviruses isolated in Southern Italy. Veterinary Microbiology, $110(6), 1-6$.

[15] Jindal SR, Maiti NK and Oberoi MS. (2000).Genomic diversity and prevalence of Rotavirus in cow and buffalo calves in northern India. Scientific and technical Review, 19(3), 871-876.

[16] LanzUhde V, KaufmannT, Sager H, Albini S, Zanoni R, Schelling E and Meylan M. (2008). Prevalence of four enteropathogens in the faeces of young diarrhoeic dairy calves in Switzerland. TheVeterinary Record, 163(3), 362-366.

[17] Radostits OM, Gay C, Hinchcliff KW and Constable PD. (2007). A text book on disease ofcattle, sheep, pigs and horse. Veterinary Medicine. $10^{\text {th }}$ Ed., Saunders Elsevier, Edinburgh, pp.74-94, 103, 262-263, 206,847.

[18] Basera SS, Singh R, Vaid N, Sharma K, Chakravarti S and Malik YPS. (2010). Detection of rotavirus infection in bovine calves by RNA-PAGE and RT-PCR. Indian Journal of Virology, 21, 144-147.

[19] Odde KJ. (1988). Survival of the neonatal calf. Veterinary Clinics of North America Food Animal Practice, 97(4), 501-508.

[20] Ammar SSM, Mokhtaria K, Tahar BB, Amar AA, Redh BA, Mohamed HI, AbdellatifN and Laid B. (2004). Prevalence of rotavirus (GARV) and coronavirus (BCoV) associated with neonatal diarrhea in calves in western Algeria. Asian pacific journal of tropical biomedicine, 13(4), 318-322.

[21] Dash SK., Tewari A, Kumar K., Goel A and Bahatia A K. (2011). Detection of Rotavirus from diarrhoeic cow calves in Mahura, India. Veterinary World, 4(12), 554-556.

[22] Masuda T, Nagai M, Yamasato H, Tsuchiaka S, Okazaki S, Katayama Y, Oba M, Nishiura N, Sassa Y, Omatsu T andFuruya T. (2014).Identification of novel bovine group A rotavirus G15P [14] strain from epizootic diarrhea of adult cows by de novo sequencing using a next-generation sequencer. Veterinary Microbiology, 171(1-2), 6673.

[23] Hajnalka P, Brigitta LS, Ferencjakab, Balasubramanian G, Simona De G, Matthijnssens J, Max C, Vito M and Krisztian B. (2013). Review of group A rotavirus strains reported in swine and Cattle. Veterinary Microbiology 165 (2013), 190-199.

[24] Fuente R, de la GA, Ruiz-Santa-Quiteria JA, LuzoÂn MCD, Garcoa S, Orden JA and GoÂmez-Bautista M. (1998). Proportional morbidity rates of enteropathogens among diarrheic dairy calves in central Spain. Preventive Veterinary Medicine, 36, 145-152. 
[25] Nourmohammadzadeh F, Davoudi Y, Abdollahpour GH and Nouri A. (2012). The prevalence of rotavirus in neonatal calf diarrhea using electron microscopic examination. Comparative clinical pathology, 21(6), 12311234.

[26] Fields BN, Knipe DM, Howley PM, Chanock RM, Melnick,JL, Monath TP, Roizman B and Straus SE. (1995). Fields Virology, $3^{\text {rd }}$ Ed, Philadelphia: Lippincott-Raven, 1625-1708.

\section{How to cite this article}

Monney JD, Adjogoua VE, Karamoko Y and Akran V. (2018). Prevalence of rotavirus infection in diarrheic newborn calves in Abidjan region, Ivory Coast. GSC Biological and Pharmaceutical Sciences, 5(2), 82-87. 